\title{
Comparing Efficiency between Conventional and Molecular Methods for Detecting Legionella pneumophilia in Dental Unit Waterline Systems
}

\author{
Aylin İslam*, Meryem Güvenir², Kaya Süer³, \\ Serap Çetiner ${ }^{1}$, Tamer Şanlıdağ $\breve{~}^{4}$ \\ ${ }^{1}$ Near East University, Dentistry Faculty, Department of Pediatric Dentistry, Near East Boulevard, \\ Nicosia/North Cyprus, Mersin 10, Turkey, 99138 \\ ${ }^{2}$ Near East University, Health Services Vocational School, Near East Boulevard, \\ Nicosia/North Cyprus, Mersin 10, Turkey, 99138 \\ ${ }^{3}$ Near East University, Faculty of Medicine, Department of Infectious Diseases and Clinical Microbiology, \\ Near East Boulevard, Nicosia/North Cyprus, Mersin 10, Turkey, 99138 \\ ${ }^{4}$ Near East University, Research Center of Experimental Health Sciences/Celal Bayar University, \\ Faculty of Medicine, Department of Clinical Microbiology, Near East Boulevard, \\ Nicosia/North Cyprus, Mersin 10, Turkey, 99138
}

Received: 2 August 2016

Accepted: 25 November 2016

\begin{abstract}
The aim of our study was to detect the prevalence of Legionella pneumophilia (L. pneumophilia) in $\mathrm{DUWL}_{\mathrm{S}}$ using standard culture technique (SCT) and the real-time polymerase chain reaction (PCR) method in order to assess the risk of L. pneumophilia contamination within a dental setting. A total of 65 water samples were collected from 16 dental units and one cold water supply system from all clinical departments. L. pneumophilia could not be detected in any of the water samples using the standard SCT $(0 \%)$, whereas L. pneumophilia was detected using real time PCR in three $(4.6 \%)$ water samples collected from the tap system. Following the detection of L. pneumophilia, the tap systems were disinfected with surface disinfectant and water samples were recollected. The recollected water samples following disinfection were negative for L. pneumophilia once analyzed using culture and real time PCR technique. Although the culture method using BCYE media is the 'gold standard' for the detection of L. pneumophilia; Real Time PCR analysis may also be a quick, useful, and sensitive method for the detection of L. pneumophilia in order to control and prevent possible infections that may arise in the dental setting.
\end{abstract}

Keywords: Legionella pneumophila, real-time polymerase chain reaction, culture, dental unit, waterline 


\section{Introduction}

Legionella pneumophilia (L. pneumophilia) is a pathogenic bacteria that spreads via waterways and is mostly isolated from such aquatic environments as airconditioning systems, water tanks of hotels, ornamental pools, shower heads, cooling towers, spas, whirlpools, and water distribution systems in hospitals, and in medical equipment that include respirators, dialyzers, inhalers, humidifiers, and balneo therapy. In addition to these environments, dental unit waterline's (DUWLs) narrow-plastic tubing structures provide an opportunity for Legionella and other bacteria for colonization and biofilm formation. These tubing systems carry water at high-speed to hand pieces and air/water sprays of dental chairs and present an optimum environment for microbial colonization [1-2].

During dental treatment, dentists use high-speed handpieces, air/water syringes, or ultrasonic devices that can lead to the expansion and inhalation of Legionella aerosols [3]. Aerosols produced during dental treatments are the most important pathway for the migration of Legionella via dental practices. $\mathrm{DUWL}_{\mathrm{S}}$ that are contaminated with Legionella may contribute to respiratory diseases among dentists, dental nurses, and patients [4]. The high prevalence of Legionella seropositivity in dental personnel supports the notion that dental healthcare staff are at a high level of risk infection [5].

The routine method used for environmental inspection of Legionella is the standard culture technique (SCT), a complex technique that includes the concentration of microorganisms from water sources by filtration and/ or centrifugation followed by heat and acid treatments prior to inoculation of the selective medium GVPC (BCYE, or buffered charcoal yeast extract agar, which contains additional supplements and antibiotics such as glycine, vancomycin, polymixin, and cycloheximide). Other methods have been developed for the detection of Legionella in aquatic environments using molecular methods in order to overcome the disadvantages associated with culture methods [6-7].

The aim of the current study was to detect the prevalence of L. pneumophilia in DUWLs, to compare the efficiency of SCT and real time PCR in detecting L. pneumophilia, and to conduct a risk assessment of L. pneumophilia contamination in a dental setting.

\section{Material and Methods}

\section{Collection of Water Samples}

A total of 65 water samples were collected from 16 dental units (two dental units from each department and one from each operating room) and one cold-water supply system (input and output taps) from clinical departments (e.g., periodontology, pedodontics, orthodontics, operative dentistry, endodontics, oral surgery, prosthodontics, and two operating rooms) between October and December 2015. The dental units were selected randomly. Water samples were collected in $1 \mathrm{~L}$ sterile glass bottles. The faculty building is supplied with a single cold-water supply system and the age of all dental units is eight years. The water samples from dental units were taken from the following four sites: outlets of air/water syringes, outlets of high-speed hand pieces, water cup fillers, and the taps of each selected unit.

\section{Processing of Water Samples}

Water samples of $1,000 \mathrm{~mL}$ were filtered through $0.45 \mu \mathrm{m}$ pore cellulose filters (Advanced Microdevices Pvt. Ltd, India) using a membrane filtration system. Filters were washed for $5 \mathrm{~min}$ in an acid buffer $(0.2 \mathrm{~mol} / \mathrm{l} \mathrm{HCl})$, then rinsed in a Page saline solution $\left(\mathrm{NaCl}, \mathrm{MgSO}_{4} \cdot 7 \mathrm{H}_{2} \mathrm{O}, \mathrm{CaCl}_{2} \cdot 2 \mathrm{H}_{2} \mathrm{O}, \mathrm{Na}_{2} \mathrm{HPO}_{4}, \mathrm{KH}_{2} \mathrm{PO}_{4}\right)$ and divided into two parts with a sterile lancet for culturing of the bacteria and DNA extraction.

\section{Isolation and Identification of Legionella strains}

Filters were placed onto BCYE containing supplements (Liofilchem, Italy). The plates were incubated at $37^{\circ} \mathrm{C}$ for 6-14 days with a daily check for growth. Suspected colonies of Legionella spp. were Gram-stained and subcultured onto selective BCYE agar (Liofilchem, Italy) and blood agar. The suspected colonies were identified to the species level and serogrouped with a Legionella Latex Kit (Microgen Legionella, UK) that supports the identification of L. pneumophila by serogroups.

\section{Real-time PCR}

All the samples were analyzed with a real-time PCR instrument using the DNA extracted from the cellulose filters using Ribospin Vrd (GeneAll Biotechnology Co., LTD) according to the manufacturer's instructions. The Real-Time PCR system (CFX 96-Real Time System, ThermalCycler C1000, Bio-Rad) was used for detection and quantification of L. pneumophila.

\section{Results and Discussion}

\section{Results}

65 water samples were tested in our study (Table 1). L. pneumophilia was not detected in any of the water samples by the SCT $(0 \%)$. Only three water samples $(4.6 \%)$ collected from the tap system were positive for L. pneumophilia using real-time PCR. According to manufacturer's instructions the following scoring system can be used to determine whether a sample is positive for $L$. pneumophilia: $(+)$ if the value is under $10^{2} \mathrm{cfu} / \mathrm{mL},(++)$ if the value is between $10^{2}-10^{5} \mathrm{cfu} / \mathrm{mL}$, and $(+++)$ if the value is greater than $10^{5} \mathrm{cfu} / \mathrm{mL}$. The three samples that tested 
Table 1. Locations and numbers of selected dental units.

\begin{tabular}{|c|c|c|}
\hline Location & Division & Number of sample \\
\hline \multirow{2}{*}{-1 Floor } & $\begin{array}{c}\text { Cold Water storage } \\
\text { tank }\end{array}$ & 2 \\
\hline \multirow{2}{*}{ Ground Floor } & Periodontology & 8 \\
\cline { 2 - 3 } & Operating Room & 4 \\
\hline \multirow{2}{*}{ First Floor } & Pedodontics & 8 \\
\cline { 2 - 3 } Second Floor & Orthodontics & 8 \\
\cline { 2 - 3 } & $\begin{array}{c}\text { Operative } \\
\text { Dentistry }\end{array}$ \\
\hline \multirow{2}{*}{ Third Floor } & Endodontics & 8 \\
\cline { 2 - 3 } & Operating Room & 3 \\
\hline Fourth Floor & Prosthodontics & 8 \\
\hline $\begin{array}{c}\text { Total 7 } \\
\text { (65 water } \\
\text { samples) }\end{array}$ & $\begin{array}{c}\text { Department and }-1 \\
\text { Floor }\end{array}$ & $\begin{array}{c}16 \text { dental units and } \\
\text { cold water supply } \\
\text { system }\end{array}$ \\
\hline
\end{tabular}

*Water samples were collected from outlets of air/water syringes, outlets of high-speed hand pieces, water cup fillers, and taps of each selected dental unit (63 water samples) *Input and output water samples were collected from cold water supply system (two water samples)

${ }^{*}$ In total, 65 water samples were collected from seven departments and one cold-water supply system

positive for L. pneumophilia were collected from the tap system of the periodontology and oral surgery departments, and the oral surgery operating room (Table 2).

After identifying the contaminated water samples, the tap systems were disinfected with a surface disinfectant (35\% ethyl alcohol, 5\% propan-2-ol, didecyl-dimethyl ammonium chloride, deionized water) and then water samples were recollected and analyzed using both SCT and real time PCR. The recollected water samples from the tap systems were found to be negative for L. pneumophilia by both methods.

\section{Discussion of Results}

High levels of respiratory diseases among dentists and dental staff compared to the general public have been

Table 2. Evaluation and comparison of Legionella pneumophila in water samples using standard culture and real-time PCR techniques.

\begin{tabular}{|c|c|c|}
\hline \multicolumn{3}{|c|}{ Legionella pneumophila Evaluation } \\
\hline Type of Water Sample & Culture & Real-Time PCR \\
\hline Tap water & $(-)$ & $3(+)^{*}$ \\
\hline DUWL $_{\mathrm{S}}$ & $(-)$ & $(-)$ \\
\hline Total & $\% 0$ & $4.6 \%$ \\
\hline
\end{tabular}

${ }^{*} \leq 10^{2} \mathrm{cfu} / \mathrm{mL}$ reported by a number of studies $[1,8]$. Composition of aerosols by air/water syringes and high-speed hand pieces during dental treatments were reported to be the cause of the spread of Legionella to dental staff and patients [9)]. In this study, we determined the risk of L. pneumophilia infection by monitoring the presence of Legionella in water supplied from the tap system from three dental units.

In 2015 the guidelines from the U.S. Centers for Disease Control (CDC) and the U.S. Environmental Protection Agency (EPA) for dental health care procedures set the microorganism quantity for safe drinking water at $\leq 500 \mathrm{cfu} / \mathrm{mL}$. According to Italian standards for safe drinking water, the acceptable microorganism concentration varies; heterotrophic plate count at $22^{\circ} \mathrm{C} \leq 100 \mathrm{cfu} / \mathrm{mL}$, heterotrophic plate count $36^{\circ} \mathrm{C} \leq 20 \mathrm{cfu} / \mathrm{mL}$ (The European Council Directive) [1, 5]. Legionella concentrations that are detected at levels of more than $10^{4}-10^{5} \mathrm{cfu}$ per liter of water constitute a risk to human health, and epidemiologic data suggests that Legionellosis outbreaks arise from these values [10]. In our study the L. pneumophilia concentrations from the three positive samples were evaluated at under $10^{2} \mathrm{cfu} / \mathrm{mL}$.

Even though the SCT allows for the isolation and the detection of $L$. pneumophilia from environmental aquatic sources, there are some associated limitations with the method: 1) Selective media is required for the culturing of $L$. pneumophilia and requires an extended incubation period (up to 14 days), 2) bacterial loss may occur during the concentration phase preceding pretreatments with acid and heat, and 3) the possible overgrowth with other microorganisms and the case of viable but non-cultivable (VBNC) L. pneumophilia [11-12].

The advantages of molecular methods, particularly real time PCR, are as follows: 1) isolation of VBNC, 2) detection of $L$. pneumophilia at very low concentrations, 3) rapid and sensitive identification of L. pneumophilia, and 4) better manipulation of large amounts of samples [13-14]. Real Time PCR can also determine the presence of non-cultivable Legionella spp., especially VBNC types [15]. Our results have shown that real-time PCR was more sensitive and less time consuming to detect the L. pneumophilia in water samples. On the other hand, real-time PCR cannot discriminate between live and dead bacterial cells. Ditommaso S. et al. reported that the L. pneumophilia detection rate was at $67 \%$ with realtime PCR compared with $46 \%$ with the culture method. Furthermore, $21 \%$ of samples tested positive by real time PCR were negative for SCT [16]. In our study, L. pneumophilia was not detected in any of the water samples by the SCT $(0 \%)$, whereas $4.6 \%$ was found to be positive with real-time PCR. Kramer A. et al. determined that contamination with L. Pneumophilia was low in dental units and L. Pneumophilia was detected in only four out of $130(3.07 \%)$ water samples [17]. In the current study, three out of $65(4.6 \%)$ water samples tested positive for the presence of L. pneumophilia. Therefore, our results are comparable to that of other studies. Ditommaso et al. reported that the load of L. pneumophilia DNA identified 
by real-time PCR was larger than the concentration of L. pneumophilia determined using SCT. The L. pneumophilia load analyzed using real-time PCR was 28 -fold higher than that detected by SCT [18]. In our study, the positive signal obtained from real-time PCR was estimated to be under $10^{2} \mathrm{cfu} / \mathrm{mL}$.

Recently, Leoni E. et al. investigated and outlined a risk management plan for L. pneumophilia-contaminated DUWLs. They reported the age, functional features, several disinfection protocols, and locations of operating rooms associated with L. pneumophilia contamination of DUWLs [1]. Previous studies reported that chemicals such as ethylene diamine tetra acetic acid, sodium hypochlorite, chlorhexidine gluconate, povidine iodine, ethanol, peroxide, phenol, and glutaraldehyde were commonly used for chemical treatments of the DUWLs [19]. In the current study, following the detection of L. pneumophilia the tap systems were disinfected with a surface disinfectant containing 35\% ethyl alcohol, 5\% propan-2-ol, didecyldimethyl ammonium chloride, and deionized water for 30 seconds. Following disinfection the recollected water samples from the tap system tested negative using both SCT and real-time PCR.

There have only been a few similar studies conducted in Turkey. The first of these was investigated and reported by Bodrumlu et al. in Ankara, Turkey [20]. Although they could not detect any Legionella spp. in any DUWLs, they were able to detect L. pneumophilia in one of the tap water samples using the SCT. In another study regarding bacterial load of dental units conducted by Güngör et al. in İstanbul, Turkey [21], Legionella was not detected in any water and aerosol samples, but Pseudomonas aeruginosa was isolated in three DUWLs. Furthermore, Pseudomonas and Staphylococcus also were found in water and aerosol samples.

\section{Conclusions}

In this study, the accumulation of polluted water on the ground floor, the rare utilization of tap water, and a deficiency of periodic disinfection protocols are considered to be the most likely causes of L. pneumophilia contamination in tap water. Our study reveals the importance and benefits of microbial detection in DUWLs and tap water. Furthermore, our results highlight the importance of changing and disinfecting tap filters routinely and flushing tap water systems.

Based on our findings, precautions should be taken in dental care environments with regards to possible L. pneumophilia contamination in the water system. Furthermore, real-time PCR may be a useful method to apply during routine controls of DUWLs and tap water systems.

\section{Acknowledgements}

This research was supported by Near East University.

\section{References}

1. LEONI E., DALlOLIO L., STAGNi F., SANNA T., D' ALESSANDRO G., PIANA G. Impact of a risk management plan on Legionella contamination of dental unit water. International Journal of Environmental Research and Public Health. 12 (3), 2344, 2015.

2. SIKORA A., WOJTOWICZ-BOBIN M., KOZIOLMONTEWKA M., MAGRYS A., GLADLYSZ I. Prevalence of Legionella pneumophila in water distribution systems in hospitals and public buildings of the Lublin region of Eastern Poland. Annals of Agricultural and Enviromental Medicine. 22 (2), 195, 2015.

3. AJAMI B., GHAZVINI K., MOVAHHED T., ARIAEE N., SHAKERI M.T., MAKAREM S. Contamination of a dental unit water line system by Legionella pneumophila in the Mashhad School of Dentistry in 2009. Iranian Red Crescent Medical Journal. 14 (6), 376, 2012.

4. ARVAND M., HACK A. Microbial contamination of dental unit waterlines in dental practices in Hesse, Germany: a cross- sectional study. European Journal of Microbiology and Immunology. 3 (1), 49, 2013.

5. DALlOLIO L., SCUDERI A., RINI M.S., VALENTE S., FARRUGGIA P., BUCCI -SABATTINI M.A., PASQUINELLI G., ACACCI A., RONCARATI G., LEONI E. Effect of different disinfection protocols on microbial and biofilm contamination of dental unit waterlines in community dental practices. International Journal of Environmental Research and Public Health. 11 (2), 2064, 2014.

6. GHOTASLOU R., YEGANEH-SEFIDAN F., AKHI M.T., SOROUSH M.H., HEJAZI M.S. Detection of Legionella contamination in Tabriz hospitals by PCR assay. Advanced Pharmaceutical Bulletin. 3 (1), 131, 2013.

7. CRISTINO S., LEGNANI P.P., LEONI E. Plan for the control of Legionella infections in long-term care facilities: role of enviromental monitoring. International Journal of Hygiene and Environmental Health. 215 (3), 279, 2012.

8. DITOMMASO S., GIACOMUZZI M., RICCIARDI E., ZOTTI C.M. Evidence of Legionella spp. colonization in dental unit waterlines: Which is the best method for risk assessment?. International Journal of Enviromental Research and Public Health. 13 (2), E211. doi: 10.3390/ ijerph13020211, 2016.

9. MA' AYEH S.Y., AL-HIYASAT A.S., HINDIYEH M.Y., KHADER Y.S. Legionella pneumophila contamination of dental unit water line system in a dental teaching centre. International Journal of Dental Hygiene. 6 (1), 48, 2008.

10. DELGADO-VISCOGLIOSI P., SOLIGNAC L., DELATTRE J.M. Viability PCR, a culture-1ndependent method for rapid and selective quantification of viable Legionella pneumophila cells in enviromental water samples. Applied and Environmental Microbiology. 75 (11), 3502, 2009.

11. AL-MATAWAH Q.A., AL-ZENKI S.F., QASEM J.A., AL-WAALAN T.E., BEN HEJI A.H. Detection and quantification of Legionella pneumophila from water systems in Kuwait residential facilities. Journal of Pathogens. 138389. doi: 10.1155/2012/138389, 2012.

12. LEE J.V., LAI S., EXNER M., LENZ J., GAIA V., CASATI S., HARTEMANN P., LUCK C., PANGON B., RICCI M.L., SCATURRO M., FONTANA S., SABRIA M., SANCHEZ I., ASSAF S., SURMAN-LEE S. An international trial of quantitative PCR for monitoring Legionella in artificial water systems. Journal of Applied Microbiology. 110 (4), 1032, 2011. 
13. TOURON-BODILIS A., POUGNARD C., FRENKIELLEBOSSE H., HALLIER-SOULIER S. Usefulness of real-time PCR as a complementary tool to the monitoring of Legionella spp. and Legionella pneumophilaby culture in industrial cooling sysytems. Journal of Applied Microbiology. 111 (2), 499, 2011.

14. BONETTA SA., BONETTA SI., FERRETTI E., BALOCCO F., CARRARO E. Evaluation of Legionella pneumophila contamination in Italian hotel water systems by quantitative real-time PCR and culture methods. Journal of Applied Microbiology. 108 (5), 1576, 2010.

15. EDAGAWA A., KIMURA A., KAWABUCHI-KURATA T., ADACHI S., FURUHATA K., MIYAMOTO H. Investigation of Legionella contamination in bath water samples by culture, amoebic co-culture, and real time quantitative PCR methods. International Journal of Environmental Research and Public Health. 12 (10), 13118, 2015

16. DITOMMASO S., RICCIARDI E., GIACOMUZZI M., ARAUCO-RIVERA S.R., CECARELLI A., ZOTTI C.M. Overestimation of the Legionella spp. load in enviromental samples by quantitative real-time PCR: pretreatment with propidiummonoazide as a tool for the assessment of an association between Legionella concentration and sanitary risk. Diagnostic Microbiology and Infectious Disease. 80 (4), 260, 2014.

17. KRAMER A., LEMANSKI S., DEMOND K., ASSADIAN O. Comparison of the ActiDes-Blue and CARELA HYDRODES techonology for the sanitation of contaminated cooling water systems in dental units. GMS Krankenhaushygiene Interdisziplinar. 7 (1), ISSN 1863-5245, 2012.

18. DITOMMASO S., RICCIARDI E., GIACOMUZZI M., ARAUCO-RIVERA S.R., ZOTTI C.M. Legionella in water samples: how can you interpret the results obtained by quantitative PCR? Molecular and Cellular Probes. 29 (1), 7 , 2015.

19. GARG S.K., MITTAL S., KAUR P. Dental unit waterline management: historical perspectives and current trends. Oral Biosciences. 3 (4), 247, 2012.

20. BODRUMLU E., ALAÇAM T., BAYRAKTAR A. Legionella in the dental office. International Journal of Dental Hygiene. 5 (2), 116, 2007.

21. GÜNGÖR N.D., KADAIFÇILER D.G., PEKER O.Ö. Investigation of the bacterial load and antibiotic susceptibility of dental units. Enviromental monitoring and assessment. 186 (3), 1847, 2014. 
